\author{
Joanna Dworzecka \\ Uniwersytet im. Adama Mickiewicza w Poznaniu (Polska) \\ Adam Mickiewicz University in Poznan (Poland) \\ e-mail: jd53808@st.amu.edu.pl \\ https://orcid.org/0000-0002-9878-3124
}

\title{
Polska i białoruska tożsamość Kościoła rzymskokatolickiego na Białorusi. Historia a współczesne dylematy
}

\author{
Polish and Belarussian identity of Roman Catholic Church in Belarus. \\ History and contemporary dilemmas \\ Польская і беларуская ідэнтычнасьщь Рыма-каталічкага Касцёла ў Беларусі. \\ Гісторыя і сучасныя дылемы
}

\begin{abstract}
This article discusses the complex identity of the Catholic Church in Belarus. It constitutes a response to the voices of several researchers postulating that the local Catholic Church declare itself part of the Polish nation. The author reflects on the possibility itself of a religion - whether as an institution or as a community of believers - having a national identity, and on how this issue is present in Belarus. Based on different theories regarding social identity, and on anthropological field research, conducted among priests and Belarusian Catholics in the years 2013-2017, she attempts to prove the coexistence of two non-exclusive national identities of the Church in Belarus, i.e. Belarusian and Polish. The author thus stands up to the critical voices blaming the ecclesial institutions for either the Belarutenization or the Polonization of their believers. According to the author, the perception of identity as variable and complex, i.e. composed of numerous affiliations, is a prerequisite for the reconciliation of the Polish and Belarusian identities of the Church without the necessity of choosing one of them - a concept compatible with the main attribute of the Catholic Church being its universality.
\end{abstract}

Keywords: national identity, Catholic Church, Belarutenization, Polonization, Belarusian Catholics 


\begin{abstract}
Abstrakt
Artykuł porusza problem złożonej tożsamości Kościoła katolickiego na Białorusi. Jest on odpowiedzią na głosy niektórych polskich badaczy domagających się, aby Kościół lokalny opowiedział się za przynależnością do narodu polskiego. Autorka rozważa w nim, czy w ogóle możliwe jest posiadanie przez konfesję, traktowaną jako instytucję, ale także wspólnotę wiernych, tożsamości narodowej oraz w jaki sposób problem ten obecny jest w Kościele na Białorusi. Odwołując się do różnych teorii społecznych tożsamości, a także antropologicznych badań terenowych, które prowadziła wśród kapłanów i białoruskich katolików w latach 2013-2017, stara się dowieść, iż na omawianym terenie miała okazję obserwować występowanie dwóch niewykluczających się tożsamości narodowych Kościoła: białoruskiej i polskiej. Tym samym przeciwstawia się krytycznym głosom, oskarżającym instytucje kościelne o białorutenizację lub polonizację wiernych. Według autorki dopiero skorygowanie sposobu postrzegania tożsamości jako zmiennej i złożonej z licznych przynależności pozwala pogodzić polską i białoruską tożsamość Kościoła bez konieczności dokonywania wyboru jednej z nich, co jest zgodne z głównym atrybutem Kościoła, za jaki uznano jego powszechność.
\end{abstract}

Słowa kluczowe: tożsamość narodowa, Kościół katolicki na Białorusi, białorutenizacja, polonizacja, białoruscy katolicy

\title{
Анатацыя
}

Артыкул разглядае праблему складанай ідэнтычнасці каталіцкага касцёла на Беларусі. Гэта рэакцыя на выказванні некаторых польскіх даследчыкаў, якія патрабуюць, каб мясцовы касцёл заявіў пра сваю прыналежнасць да польскага народа. Аўтар разважае, ці наогул магчыма, каб канфесія як інстытуцыя, але адначасова і супольнасць вернікаў, магла мець нацыянальную ідэнтычнасць, а таксама ў якой ступені гэтая праблема датычыць касцёла на Беларусі. На падставе розных тэорый ідэнтычнасці, а таксама ўласных антрапалагічных палявых даследаванняў, якія праводзіліся сярод святароў і беларускіх католікаў у перыяд 2013-2017 гг., аўтар прагне даказаць, што на даследаванай тэрыторы суіснуюць дзве нацыянальныя ідэнтычнасці каталіцкіх вернікаў, яны не выключаюць сябе ўзаемна: беларуская і польская. Такім чынам, вынікі даследавання абвяргаюць крытычныя меркаванні, у якіх інстытуцыя касцёла абвінавачваецца ў беларусіфікацыі або паланізацыі католікаў. Паводле аўтара, толькі карэкта спосабу разумення ідэнтычнасці як зменнай і складзенай са шматлікіх элементаў прыналежнасці дазваляе прыняць адначасова польскую і беларускую ідэнтычнасць касцёла без неабходнасці абавязкова выбіраць адну сярод іх. Выказаная выснова адпавядае галоўнай характэрнай рысе Царкве ўвогуле, менавіта, яе ўсеагульнасці.

Ключавыя словы: нацыянальная ідэнтычнасць, каталіцкая царква на Беларусі, беларусізацыя, паланізацыя, беларускія католікі 
$\mathrm{P}$ ostawiony przeze mnie w tytule problem badawczy w dość przewrotny sposób traktuje Kościół katolicki na Białorusi - nie jako depozyt lub ostoję tożsamości narodowych lokalnych społeczności, jak czyniło to wielu badaczy, ale jako konfesję, która także posiada swoją tożsamość, w tym narodową. Na początku wypada wyjaśnić dwie fundamentalne kwestie. Po pierwsze, czy Kościół, traktowany tu przeze mnie zarówno jako instytucja religijna, jak i wspólnota wiernych, ma własną tożsamość? Po drugie, czy w przypadku konfesji - a zwłaszcza katolicyzmu - mam prawo mówić o tożsamości narodowej?

Odpowiadając na pierwsze z wymienionych pytań, pragnę odnieść się do pojęcia tożsamości zbiorowej. Jej przeciwnicy twierdzą, że „nie należy mówić o tożsamości zbiorowej ze względu na niebezpieczeństwo fałszywego hipostazowania" (Ziętek, 2008, s. 49). Inne stanowisko prezentuje Anthony Giddens (2004, s. 736), uwzględniający w definicji tożsamości zarówno jej indywidualny, jak i grupowy wymiar. Podobne podejście do problemu ma Zbigniew Bokszański, który proponuje spojrzeć na to pojęcie jako na ,syntezę tradycyjnych terminów używanych w analizach różnic kulturowych z nowym sposobem pojmowania podmiotu indywidualnego, związanym z pojęciem tożsamości” (za: Ziętek, 2008, s. 49). Jak wynika z prowadzonych przeze mnie w latach 2013-2017 obserwacji antropologicznych Kościoła na Białorusi, ze względu na specyficzne uwarunkowania społeczno-polityczne, częściowo determinujące jego postawę, teorie odnoszące się do tożsamości indywidualnej warto wykorzystać w badaniach tożsamości zbiorowej. Dlatego posłużę się koncepcją tożsamości Edwina Ardenera (1992, s. 32), która ujmowana jest jako ,samotworzenie i zewnętrzna identyfikacja". W antropologicznych badaniach nad wspomnianym terminem zwraca się szczególną uwagę na to, wokół jakich norm i wartości grupa lub jednostka buduje tożsamość oraz jaka jest jej pamięć zbiorowa. Ponieważ - jak wspomniałam na wstępie - Kościół przez lata był narzędziem podtrzymywania i kształtowania tożsamości narodowych na Białorusi, posiadał spójny zespół norm i „wspomnień”, do których się odnosił, a jednocześnie był z nimi identyfikowany.

W tym miejscu warto odpowiedzieć na drugie z postawionych pytań. Na początku lat 90. XX w. Kościół katolicki na obszarach białoruskich, nie tracąc powszechnego charakteru, identyfikował się oraz był identyfikowany (i nadal często jest), tak na poziomie instytucjonalnym, jak i jednostkowym, z narodem polskim (Kabzińska, 1999, s. 21-22).

Powstanie Kościoła unickiego pod koniec XVI w. i jego działalność stworzyły natomiast przestrzeń do legitymizacji i rozwoju tożsamości narodowej białoruskiej. Obie konfesje, należące do Kościoła powszechnego, nie były podzielone i w wielu sytuacjach współpracowały. Warto wspomnieć chociażby o zaangażowaniu kapłanów rzymskokatolickich i unickich w powstanie listopadowe czy o udziale duchowieństwa rzymskokatolickiego w organizowaniu i utrzymaniu Kościoła unickiego. Gdy w 1839 r. zlikwidowana została unia - pomimo zakazu rządu carskiego - wielu unitów przeszło do Kościoła łacińskiego. Jak podaje Sergiej Nechames (1993, s. 72): „liczba katolików zwiększyła się z ok. 15\% nawet do 40\%”. W drugiej połowie XIX w. część spolonizowa- 
nej szlachty białoruskiej, będącej katolikami, zaczęła uświadamiać sobie swoje białoruskie pochodzenie. Od 1913 r. ukazywał się katolicki tygodnik „Biełarus”, który stworzył fundamenty białoruskiej myśli konserwatywnej (Mironowicz, 2007, s. 21).

Losy katolików - Polaków i Białorusinów - dowodzą posiadania przez wiernych dwóch niewykluczających się przynależności narodowych, funkcjonujących w ramach jednej tożsamości Kościoła na białoruskich ziemiach. W ostatnich latach tożsamość ta ulega gwałtownym przeobrażeniom. Pragnę w tym miejscu zaznaczyć, że traktuję tożsamość jako zbiór różnych przynależności (identyfikacji + autoidentyfikacji), który ulega zmianom w czasie ${ }^{1}$. Oczywiście przynależność narodowa nie jest jedyną, ani nawet dominującą, przynależnością katolicyzmu na Białorusi, lecz stanowi zaledwie część składową tożsamości. Ośmielam się mówić o polskiej i białoruskiej tożsamości Kościoła właśnie jako o takiej, która zawiera w sobie wspomniane dwie przynależności, ale także wiele innych.

Zjawisko łączenia tożsamości religijnej z narodową nie jest jedynie typowo białoruskim fenomenem. Jak twierdzi Meredith McGuire (2012, s. 369): ,pojawienie się kultur narodowych w Europie wczesnonowożytnej było silnie związane z tożsamością narodowo-religijną". Podaje przy tym jako exemplum związki tożsamości luterańskiej ze szwedzką czy anglikańskiej z angielską. Unikatowe jest natomiast godzenie przez Kościół i jego wiernych dwóch przynależności: polskiej i białoruskiej (choć nie są to już tak jednoznaczne identyfikacje). Przykładem może być wypowiedź jednej z parafianek z diecezji pińskiej:

Jestem Polką, ponieważ moje korzenie są polskie - dziadkowie byli Polakami, ale jestem też Białorusinką, bo tu się urodziłam, wychowałam w tej kulturze, mówię tutejszym językiem, a polski znam słabo, tyle co od dziadków i rodziców, no i z kościoła².

Wypowiedź ta wskazuje na historyczne źródła skomplikowania tożsamości narodowej białoruskich katolików, ale także Kościoła w znaczeniu instytucjonalnym, który odgrywając istotną rolę w historii sam niejako podlega jej wpływom.

\section{Historia}

Ziemie współczesnej Białorusi należące do dawnej Rusi Kijowskiej były chrystianizowane już w IX w. za sprawą Bizancjum (Dudik, 2007, s. 20). Istnieje także teoria o ,przedwłodzimierskim” chrzcie z rąk łacińskich misjonarzy w VIII i X w. (Necha-

\footnotetext{
Skłaniam się ku koncepcji tożsamości Amina Maaloufa (2002, s. 10-31), który zauważa, że „w każdym człowieku stykają się liczne przynależności. Nie zawsze żyją one ze sobą w zgodzie i czasem zmuszają do dokonywania trudnych wyborów. [...] Tożsamość nie jest dana człowiekowi raz na zawsze, ona się tworzy i przeobraża w ciągu całego naszego życia".

2 Informator: kobieta, 31 lat, zamieszkała w Baranowiczach. Wywiad z 16.08.2014 r.
} 
mes, 1993, s. 68). Najazdy tureckie i napływ pogańskich ludów litewskich zahamowały rozwój chrześcijaństwa na omawianym obszarze. Dopiero w XIII w. wraz z powstaniem Księstwa Litewskiego książę Mendog zdecydował się na przyjęcie chrztu za pośrednictwem mistrza zakonu kawalerów mieczowych (Dudik, 2007, s. 28-29). Niedługo potem Mendog popadł w konflikt z zakonem i wyrzekł się katolicyzmu. W XIV w. książę Władysław Jagiełło, chcąc przeciwdziałać wyprawom krzyżackim na Litwę, zdecydował się przyjąc chrzest w obrządku łacińskim za pośrednictwem Polski. W tym czasie większość Litwinów, zwłaszcza z warstwy wyższej, była już chrześcijanami obrządku prawosławnego. Konieczność ponownego chrztu często budziła sprzeciw możnowładców, którzy później wielokrotnie stawali po stronie książąt moskiewskich. Kolejnym istotnym wydarzeniem dla sytuacji chrześcijaństwa było zawarcie unii brzeskiej. Cerkiew greckokatolicka cieszyła się dużą popularnością wśród ludności wiejskiej, a w przededniu zaborów należało do niej aż 75\% ludności; pozostałą część stanowili katolicy (18\%) rzymscy oraz prawosławni (6,5\%).

Zabory doprowadziły do kasaty unii i włączenia jej do Cerkwii prawosławnej, dzięki czemu pod koniec XIX w. prawosławie stało się wyznaniem dominującym na ziemiach białoruskich. W tym czasie rzymski katolicyzm był systematycznie kontrolowany i osłabiany - zwłaszcza po upadku powstania listopadowego, kiedy zamykano klasztory, a kościoły przekształcano w cerkwie, a także po klęsce powstania styczniowego. 25 grudnia 1869 r. wszedł w życie ukaz cara Aleksandra II zalecający wprowadzenie języka rosyjskiego zamiast języka polskiego do nabożeństw (pogrzebów, adoracji, nieszporów) oraz katechez. Wydano w tym celu tzw. Trebnik, czyli książkę zawierającą teksty nabożeństw, sakramentów i modlitw. Roman Dzwonkowski tak opisuje te wydarzenia:

Aleksander II powołał komisję złożoną z najwyższych urzędników państwa, która przygotowała program dotyczący likwidacji języka polskiego w kościołach. Był nim tzw. Triebnik, czyli rytuał w języku rosyjskim. Wydany został w Wilnie w 1869 i 1870 r. Zawierał teksty tradycyjnych nabożeństw katolickich w tym języku odprawianych poza Mszą św. (nieszpory, nabożeństwa majowe, adoracje, pogrzeby i inne). Jednocześnie wydane zostały kazania na niedziele i święta w języku rosyjskim, śpiewnik kościelny, katechizm oraz modlitewnik dla wiernych ${ }^{3}$.

Mimo licznych zachęt ze strony władz państwowych i uległych wobec nich hierarchów kościelnych (w tym np. metropolity mohylewskiego Maksymiliana Staniewskiego), którzy starali się skłonić wiernych do przyjęcia ukazu, rozporządzenie spotkało się ze sprzeciwem duchowieństwa i wiernych (Dudik, 2007, s. 66). W 1925 r. Witold Czeczot w publikacji Dyecezya mińska i jej pasterz Zygmunt Łoziński opisał sposób argumentacji katolickich chłopów broniących się przed zmianami:

3 Dzwonkowski, Roman. (2017). Kościół katolicki w służbie rusyfikacji - plan caratu. Echa Polesia. Pobrano z: http://polesie.org/5858/5858/ (dostęp: 20.04.2018). 
Prawda, że my nie jesteśmy czystymi Polakami, ale nie jesteśmy też Moskalami. Z Polski przyszła do nas wiara katolicka i dlatego po polsku modlimy się w domu i w kościele, a kiedy ksiądz mówi kazanie, to choć mówi po polsku, my go rozumiemy. Tego zaś, co mówi pop moskiewskim językiem - my wcale nie rozumiemy (1925, s. 8).

Jednocześnie autor zauważa, że byli też kapłani, którzy „stali się narzędziem moskiewskiego rządu i rusyfikacji katolickich kościołów w Mińszczyźnie”, jak np. ks. Franciszek Ferdynand Sęczykowski w Ihumieniu, Błoniu i Bobrujsku (Czeczot, 1925, s. 9-10). Wielu księży w obawie przed osieroceniem parafii starało się nie prowokować władz i ograniczało pracę duszpasterską do modlitwy.

Rodząca się w drugiej połowie XIX w. tożsamość narodowa Białorusinów miała dwa oblicza: prawosławne - zainteresowane autonomią w ramach nowego tworu, jakim miałaby być federacyjna Rosja - oraz katolickie, zorientowane bardziej na niezależność od Rosji i współpracę z Polską (Mironowicz, 2007, s. 12-15). Do tego momentu istniało już pojęcie „Białoruś”, jednak wykorzystywano je jako określenie obszaru geograficzno-kulturowego innych struktur państwowych. Dla Polaków Białorusini byli „kresowym ludem polskim”, a więc grupą etniczną należącą do narodu polskiego. Wydaje się to przyczyną występowania wśród katolików dwóch niewykluczających się przynależności. Jak podaje Dariusz Tarasiuk (2004, s. 133), na pytanie o narodowość polską i białoruską większość mieszkańców ziem białoruskich mogła odpowiedzieć: ,,jestem zarówno jednym, jak i drugim”. Dla Rosjan Białorusini byli ludem tworzącym naród rosyjski, do którego zaliczano: Wielkorusów (Rosjan), Małorusów (Ukraińców) i Zapadnorusów (Białorusinów) (Mironowicz, 2007, s. 12). Podział religijny, mający do XIX w. większe znaczenie niż państwowy, spowodował wykształcenie się dwóch poglądów na sprawę białoruską, których konsekwencje widoczne są do dziś w różnicach poglądów politycznych katolików i prawosławnych ${ }^{4}$.

Gdy Polska odzyskała niepodległość, Kościół katolicki otrzymywał liczne przywileje od władz II Rzeczpospolitej. Podpisano konkordat ze Stolicą Apostolską, rewindykowano majątki kościelne, rozwijała się nauka religii i działalność misyjno-charytatywna (Stępniak, 2005, s. 316). Za sprawą bp. Zygmunta Łozińskiego powstała neounia. Dzięki wsparciu rządu Kościół prawosławny w Polsce ogłosił autokefalię. Inaczej wyglądała sytuacja w Białoruskiej Socjalistycznej Republice Radzieckiej (BSRR), gdzie od początku religię traktowano jako „opium dla ludu”. Państwo zwalczało przede wszystkim Cerkiew prawosławną, ale także szykanowało katolików, nazywając ich „agentami Watykanu” lub „spolonizowanymi Białorusinami”. W przeddzień II wojny światowej nie było tu ani jednego czynnego kościoła czy duszpasterza, pozostały tylko dwie cerkwie (Dudik, 2007, s. 80).

4 Jak podaje Nechames (1993, s. 73): „Jeżeli jeszcze w latach 1988-1989 wśród członków młodzieżowych stowarzyszeń patriotycznych, utożsamiających się z przedstawicielami jednego z wyznań chrześcijańskich, część rzymsko- i grekokatolików wynosiła zaledwie 30-35\%, to już w 1991 roku zwiększyła się ona do 80-85\% (łącznie z grekokatolikami)”. 
Po wojnie plan likwidacji Kościoła na nowych (zachodnich) terenach BSRR rozłożono w czasie. W połowie lat 80. pracowało tam jeszcze 54 księży (Dzwonkowski, 1993, s. 170). Mimo niedoboru kapłanów katolicyzm przetrwał, często w synkretycznej, ludowej formie. Na początku lat 90. na Białoruś przybyło wielu polskich księży, którzy pomogli w odbudowie katolicyzmu w nowo powstającej republice. Najważniejszym wydarzeniem po odtworzeniu struktur kościelnych okazał się synod obradujący w latach w 1996-2000, jego owocem jest opublikowany w 2002 r. dokument regulujący obecne życie religijne katolików - Statuty Synodu Archidiecezji Mińsko-Mohylewskiej, Pińskiej i Witebskiej. Został on zapisany w języku białoruskim i polskim. Posynodalne zmiany w Kościele dotyczą przede wszystkim języka nabożeństw - język białoruski oficjalnie został ogłoszony językiem Kościoła katolickiego na Białorusi, zaś polski ma pełnić funkcje pomocnicze i być używany jedynie, gdy zachodzi potrzeba duszpasterska. W trakcie synodu kościół Wniebowzięcia Najświętszej Maryi Panny w Budsławiu uznany został za narodowe sanktuarium Białorusi ${ }^{5}$. Obecnie pielęgnuje się historię katolicyzmu na tych ziemiach oraz kult żyjących tu świętych i błogosławionych, m.in.: św. Jozafata Kuncewicza, św. Kazimierza, jedenastu sióstr nazaretanek z Nowogródka. Upamiętnia się również sługę Bożego bp. Zygmunta Łozińskiego czy ks. kard. Kazimierza Świątka (inicjatora synodu).

\section{Dylematy}

Wpływ na kształtowanie się tożsamości Kościoła katolickiego na Białorusi miały czynniki zewnętrzne, zwłaszcza sytuacja polityczna i związana z nią działalność propagandowo-popularyzatorska, oraz czynniki wewnętrzne, w szczególności indywidualne wybory wiernych i duszpasterzy. Przyczyniło się to do uformowania w ramach katolickiej tożsamości dwóch przynależności narodowych. Dla wielu środowisk propolskich taka sytuacja jest nie do przyjęcia. Na początku XXI w. pojawiło się więc pytanie, w jakim kierunku zmierza rozwój tożsamości Kościoła na Białorusi: czy będzie to polonizacja, czy też białorutenizacja kultu. Obie tendencje uwarunkowane są historycznie i politycznie, dotyczą narodowej identyfikacji instytucji kościelnych oraz wiernych.

Ważnymi zdarzeniami historycznymi uzasadniającymi polski charakter Kościoła na Białorusi są unia w Krewie i chrzest Litwy. Wielkie znaczenie przypisuje się także roli katolicyzmu w podtrzymywaniu tożsamości polskiej w dobie zaborów i w czasach BSRR oraz działaniom polskich kapłanów, którzy po upadku ZSRR zaangażowali się w odrodzenie instytucji Kościoła. Popularne powiązanie „Polak-katolik” opiera się właśnie na tych filarach ${ }^{6}$. Traktowanie katolicyzmu jako „wiary polskiej” wywodzi

5 Koronacja obrazu Matki Bożej Budsławskiej odbyła się 02.07.1998 r. Por. http://catholic.by/2/pl/ belarus/sanctuarium/101102-budsaw.html (dostęp: 14.06.2017).

6 Chodzi przede wszystkim o taki sposób legitymizowania polskiej przynależności narodowej przy pomocy katolicyzmu, gdy pochodzenie wiernych utożsamia się z „polską” historią Kościoła rzymskokatolickiego na Białorusi. 
się z czasów polsko-litewskiej unii personalnej (Nechames, 1993, s. 72). Podczas zaborów pojęcie „Polak-katolik” stało się narzędziem propagandy carskiej, która, próbując przekonać ludność białoruską do przejścia na prawosławie, udowadniała, że ruskojęzyczność oznacza przynależność do prawosławia (Czeczot, 1925, s. 8). Także w rodzącej się wśród prawosławnych Białorusinów idei narodowej utożsamiano wszystkich katolików z narodem polskim, a więc elementem obcym na tych ziemiach (Mironowicz, 2007, s. 12-13). Taki sposób myślenia popularyzowała propaganda radziecka - głoszono, że Kościół polonizuje etnicznych Białorusinów, zmuszając ich do modlitwy w języku polskim, a księża są polskimi lub watykańskimi agentami. Desakralizacja życia w BSRR miała uderzyć także w polską świadomość narodową katolików, nazywanych spolonizowanymi i „okatoliczonymi” Białorusinami. Taka tożsamość wiernych była niezgodna z polityką państwa dążącego do powstania politycznie homogenicznego narodu sowieckiego (Winnicki, 2010, s. 151). Jak podaje Iwona Kabzińska, określenie „Polak-katolik” zawiera informację o wyznaniu jako podstawowym wyznaczniku tożsamości wielu osób mieszkających na Białorusi. „Operują nim osoby spoza tej grupy, często w znaczeniu pejoratywnym” (Kabzińska, 1999, s. 21).

Jednak nie tylko zewnętrzne okoliczności kształtowały polską tożsamość katolików. Również sami wierni, zwłaszcza osoby starsze, upominają się o polską mowę w Kościele, ponieważ jest to język modlitwy ich rodziców (Polaków), przekazanej im kultury i wychowania. W pewnym sensie stanowi więc legitymizację ich polskiej tożsamości narodowej. Diecezja grodzieńska, która nie uczestniczyła w synodzie, zachowała polski język nabożeństw, czasopism katolickich oraz jego dominację w nauczaniu w seminariach. O przywiązaniu do polskości na Grodzieńszczyźnie opowiadał jeden z lokalnych kapłanów:

Gdy prowadziłem msze dla dzieci, podczas kazania zadawałem im pytania po polsku. Okazało się, że ja pytam ich o jedno, a oni odpowiadają mi drugie. Zupełnie nie rozumieli, o co ich pytam. Zacząłem więc głosić kazania po białorusku. To nie spodobało się władzom diecezjalnym i zostałem przeniesiony do innej diecezji ${ }^{7}$.

Opisane powyżej zdarzenie dotyczy diecezji grodzieńskiej, która, powołując się na własne tradycje i nie przyjmując decyzji synodu, w dużej mierze odcina się od białoruskiej przynależności narodowej. Mówi się niekiedy o niej jako o „bastionie polskości" na Białorusi. W pozostałych diecezjach (uczestniczących w procesach posynodalnych) dochodzi do ożywienia białoruskiej przynależności. Przeciwnicy przemian mówią raczej o białorutenizacji Kościoła niż o jego polonizacji.

Samo zjawisko białorutenizacji nie jest nowe. Moi rozmówcy zauważali, że język białoruski (obok łaciny i polskiego) prawdopodobnie zawsze był obecny w Kościele w Wielkim Księstwie Litewskim, zwłaszcza wśród uboższej ludności. Nie miał jednak nigdy statusu dominującego. W zapiskach z dzienników bł. bp. wileńskiego Jerzego

\footnotetext{
7 Informator: mężczyzna, ok. 50 lat, pracujący w diecezji witebskiej. Wywiad z 15.07.2014 r.
} 
Matulewicza odnotowane są informacje o kapłanach nauczających po białorusku lud nierozumiejący polskiego. Sam biskup nauczył się języka białoruskiego i wydał zgodę na głoszenie w nim kazań, w 1921 r. został za to skrytykowany w prasie i odstąpił od dalszych działań w tym kierunku, stwierdzając, że jeszcze nie czas na wprowadzanie języka białoruskiego, choć w przyszłości zmiany będą nieuniknione (Ocytko, 2005, s. 283).

Prawdziwy spór o białorutenizację Kościoła rozgorzał jednak dopiero siedemdziesiąt lat po epizodzie przedstawionym przez ks. bp. Matulewicza, a Kościół lokalny przekonał się, jak prorocze okazały się jego słowa. Już na początku lat 90 . pojawiły się próby wprowadzania języka białoruskiego do liturgii, co rozpoczęło trwający do dziś, z różnym natężeniem, konflikt. Jego stronami są osoby starsze polskiego pochodzenia i niektórzy członkowie Związku Polaków na Białorusi (a także inni polscy działacze) oraz Kościół rzymskokatolicki na Białorusi, w tym przede wszystkim diecezje biorące udział w posynodalnym procesie zmian.

Białorutenizację definiuję jako zmianę orientacji w Kościele katolickim z narodowo-polskiej na białoruską, odnoszącą się w większej niż dotąd mierze do powszechności Kościoła (Dworzecka, 2016, s. 116). Konflikt o białorutenizację Kościoła apogeum osiągnął pod koniec lat 90., kiedy wielu kapłanów zaczęło prowadzić nabożeństwa w języku białoruskim. Sytuacja zaostrzyła się, gdy w 2000 r. przyjęte zostały Statuty Synodu Archidiecezji Mińsko-Mohylewskiej, Diecezji Pińskiej i Witebskiej. Wielu polskich działaczy oraz katolików o polskich korzeniach uznało zawarte w nich sformułowania za atak na własną tożsamość. Dobrze stanowisko to scharakteryzowała Kabzińska:

Kościół, modlitwa, liturgia i święta religijne bez języka polskiego, jak to już coraz częściej się zdarza, będą służyć ich (Polaków) wynarodowieniu, gdyż utracą oni możliwość publicznego manifestowania swej własnej kultury religijnej i polskości (za: Gołachowska, 2012, s. 22).

Za winnych tej sytuacji uważa się przede wszystkim młodych księży przybyłych z Polski, którzy nie znali historii i, sądząc wiernych po pozorach - takich jak słabsza znajomość języka polskiego - narzucali tutejszym katolikom białoruski język modlitwy.

Kapłani, wśród których prowadziłam badania, wprowadzając zmiany, kierowali się zasadą, że nie ma Kościoła ani polskiego, ani białoruskiego, ani jakiegokolwiek innego - jest jeden Kościół powszechny. Wierni powinni więc, o ile jest to możliwe, niezależnie od przynależności narodowej, mieć możliwość wyrażania i pogłębiania wiary w zrozumiałym dla siebie języku'. Wprowadzenie języka białoruskiego miało być nie tyle odcięciem się od polskości, ile otwarciem na innych wiernych, Białorusinów, a także żyjących na Białorusi rosyjskojęzycznych przybyszów z pozostałych

Dokumentem zezwalającym na użycie języków narodowych w liturgii jest posoborowa Druga Instrukcja o Należytym Wykonywaniu Konstytucji o Świętej Liturgii (z 1967 r.). Por. http://www. kkbids.episkopat.pl/index.php?id=89\#id=90 (dostęp: 04.06.2017). 
republik dawnego Związku Radzieckiego, dla których język ten jest bardziej zrozumiały niż polski.

Nie należy zapominać o powodach politycznych i prawnych, dla których odstępuje się od podkreślania polskiej przynależności. Dokumentem prawnym regulującym obecne życie religijne na Białorusi jest Ustawa $R B O$ wolności wyznania i organizacjach religijnych z dnia 17 grudnia 1992 r, nr 2054-XII', uzupetniona i zmieniona 31 X 2002 r. W artykule siódmym ustawy czytamy: „zabrania się działalności organizacji religijnych, skierowanej przeciwko suwerenności Republiki Białoruś, jej ustrojowi konstytucyjnemu i solidarności społecznej” (Wierzbowska-Miazga, 2001, s. 28-29). Msze święte w języku polskim z tradycyjnymi pieśniami mogą nawiązywać do polskiego patriotyzmu, a więc zagrażać solidarności społecznej i być interpretowane jako złamanie prawa.

Wybór białoruskiego języka nie wynikał jedynie z okoliczności czy aktualnego stanu rzeczy, ponieważ gdyby tak było, katolicy na Białorusi modliliby się po rosyjsku, czyli w języku, w którym mówi 70\% mieszkańców tego kraju ${ }^{10}$. Władzom kościelnym, wydającym decyzje o językach nabożeństw, chodziło raczej o umocnienie białoruskiej tożsamości w rusyfikowanym narodzie. Ponadto wprowadzenie rosyjskiego oznaczałoby wystąpienie przeciw własnej tożsamości, opartej na historii walk o zachowanie niepodległości, oraz identyfikacji narodowej i religijnej najpierw w carskiej Rosji, a później w Związku Radzieckim. Tę postawę Kościół wyraził we Wprowadzeniu do Statutów Synodu (2002, s. 370-371):

To prawda, że Synod jest instytucją Kościoła Katolickiego [...], ale jego prace i uchwały mają bezpośredni lub pośredni wpływ na społeczeństwo państwa, w którym jest sprawowany [...]. Mamy świadomość, że dokumenty Synodu wyznaczają główne kierunki w marszu Kościoła na Białorusi ku „nowemu”, które rodzi się po kulturowych i politycznych wstrząsach XX w. Kościół Katolicki na Białorusi odczuwa bowiem silną potrzebę wypowiedzenia się na rzecz społeczeństwa tej ziemi i chce być - zgodnie z pragnieniem Jana Pawła II - ,znakiem nadziei dla wszystkich tych, którzy poświęcają swoje siły dla lepszej przyszłości we wzajemnym pokoju i zgodzie".

\section{Wnioski}

Gdy polscy kapłani przybywali w latach 90. na Białoruś, zastawali wśród wiernych sytuację, którą można określić jako tożsamościowy chaos. Jeden z rozmówców opisał ją w następujący sposób:

9 W oryginale: Закон РБ „О свободе вероисповеданий и религиозных организациях”.

10 Według badań Państwowego Komitetu Statystycznego Republiki Białoruś z 2009 r. 53\% obywateli uważa język białoruski za ojczysty, a dla $41 \%$ jest nim rosyjski. W domu po białorusku mówi zaledwie 23\% społeczeństwa; większość (70\%) używa rosyjskiego. Por. http://www.belstat.gov. by/informatsiya-dlya-respondenta/ (dostęp: 04.05.2018). 
Ja się zdziwiłem, gdy przyjechałem tutaj z Ukrainy. Myślałem, że oni też, jak Ukraińcy, mówią po białorusku na przykład. Nie. Po rosyjsku gadają wszyscy. Potem idę msze odprawiać. Po polsku wszystko! Mówię do nich: Ale wy jesteście Białorusinami. Odpowiadają: No tak. To mówię: Dajcie mi jakieś teksty, bym mógł po białorusku się modlić. Nic nie było. To był 1999 rok. Dopiero w 2001 udało mi się zdobyć jakiś studyjny mszał i zacząłem chyba jako pierwszy w mieście po białorusku msze robić ${ }^{11}$.

Obecnie w wielu kościołach (zwłaszcza w parafiach zamieszkałych przez mniejszość polską) odprawia się przynajmniej jedną mszę niedzielną w języku polskim, a pozostałe po białorusku. Pojawiają się też msze wielojęzyczne, np. śpiewy i teksty z mszału w języku polskim, liturgia Słowa po białorusku, a ogłoszenia duszpasterskie po rosyjsku. Odnoszę wrażenie, że ten mieszany wariant paradoksalnie jest najlepiej przyjmowany przez członków Kościoła, ponieważ zachowano tradycyjne śpiewy i modlitwy, lektura pisma, ogłoszenia są zrozumiałe tak dla starszych, jak i młodszych.

Tożsamościowe dylematy Kościoła i jego wiernych ukształtowane przez niełatwą historię białoruskich ziem wynikają w znacznym stopniu z przyjęcia przez nich nieprzystającej do obecnej sytuacji koncepcji tożsamości. Traktowanie jej jako spójnego i niezmiennego sposobu postrzegania siebie i bycia identyfikowanym wyklucza zarówno możliwość występowania $\mathrm{w}$ ramach jednej tożsamości dwóch przynależności narodowych (zwłaszcza gdy próbuje się utożsamiać konfesję z konkretnym narodem), jak i możliwość zmian. Uznanie definicji, która uwzględnia możliwość modyfikacji, złożoność oraz zwalania z konieczności uznania logicznej spójności tożsamości pomaga godzić konflikty między zwolennikami polskiej i białoruskiej przynależności Kościoła. Już w czasach zaborów rozumieli ową dwoistość białoruscy chłopi, walczący przeciw narzucaniu im prawosławia, o których na początku XX w. napisał Jan Czeczot (1925, s. 9): „A ja wiedau, szto moja skóra mocniejsza od waszej wiery. Powiedział to chłop białoruski w swoim rodowitym języku, ale cierpiał za wiarę polską, którą za swoją uznaje".

Dopiero zaakceptowanie faktu, że katolicyzm - uformowany pod wpływem polskich, ale także rodzimych, białoruskich norm i wartości - posiada hybrydową tożsamość, pozwoli budować dalsze losy Kościoła w zgodzie i jedności.

11 Informator: mężczyzna, ok. 45 lat, pracujący w diecezji pińskiej. Wywiad z 24.07.2014 r. 


\section{Bibliografia}

\section{Źródla}

Statuty Synodu Archidiecezji Mińsko-Mohylewskiej, Diecezji Pińskiej i Witebskiej (2002). Mińsk: Pro Christo.

\section{Opracowania}

Ardener, Edwin. (1992). Tożsamość i utożsamienie. Zeszyty Naukowe Uniwersytetu Jagiellońskiego. Prace Socjologiczne, 15, s. 21-42.

Czeczot, Witold. (1925), Dyecezya Mińska i jej pasterz biskup Zygmunt Łoziński. Wilno: Druk Józefa Zawadzkiego.

Dudik, Aleksander. (2007). Sytuacja wyznaniowa i ekumeniczna na Białorusi w latach 19882003. Sandomierz: Wydawnictwo Diecezjalne i Drukarnia w Sandomierzu.

Dworzecka, Joanna. (2016). Spór o białorutenizację Kościoła katolickiego na Białorusi. Collectanea Theologica, 2, s. 115-139.

Dzwonkowski, Roman. (1993). Kościół katolicki na Białorusi - przemiany i problemy. Sprawy Narodowościowe, 1(2), s. 163-176.

Dzwonkowski, Roman. (2017). Kościół katolicki w stużbie rusyfikacji - plan caratu. Echa Polesia. Pobrano z: http://polesie.org/5858/5858/ (dostęp: 20.04.2018).

Foligowski, Przemysław. (1999). Białoruś. Trudna niepodległość. Wrocław: Alta2.

Giddens, Anthony. (2004). Socjologia. Warszawa: Wydawnictwo Naukowe PWN.

Golachowska, Ewa. (2012). Jak mówić do Pana Boga? Wielojęzyczność katolików na Białorusi na przełomie XX i XXI wieku. Warszawa: Instytut Slawistyki PAN i Wydawnictwo Agade Bis.

Kabzińska, Iwona. (1999). Wśród „Kościelnych Polaków”. Wyznaczniki tożsamości etnicznej (narodowej) Polaków na Białorusi. Warszawa: Biblioteka Etnografii Polskiej.

Maalouf, Amin. (2002). Zabójcze tożsamości. Warszawa: PIW.

McGuire, Meredith B. (2012). Religia w kontekście społecznym. Kraków: Zakład Wydawniczy NOMOS.

Mironowicz, Eugeniusz. (2007). Białoruś. Warszawa: Wydawnictwo TRIO.

Nechames, Sergiej. (1993). Stosunki międzywyznaniowe oraz narodowo-wyzwoleńczy ruch na Białorusi. W: Irena Borowik, Andrzej Szyjewski (red.). Religie i kościoły w społeczeństwach postkomunistycznych (s. 68-74). Kraków: Zakład Wydawniczy NOMOS.

Ocytko, Małgorzata. (2005). Problem Białorusinów katolików w diecezji wileńskiej w okresie ordynariatu biskupa Jerzego Matulewicza (1918-1925). W: Marek Kietliński, Krzysztof Sychowicz, Wojciech Śleszyński (red.). Kościoły a państwo na pograniczu polsko-litewsko-białoruskim. Źródła i stan badań (s. 250-263). Białystok: Wydawnictwo Prymat Mariusz Śliwkowski.

Stępniak, Władysław. (2005). Konkordat między Stolicą Apostolską a Rzeczpospolitą Polską z dnia 10 lutego 1925 r. W: Marek Kietliński, Krzysztof Sychowicz, Wojciech Śleszyński (red.). Kościoły a państwo na pograniczu polsko-litewsko-białoruskim. Źródła i stan badań (s. 284-292). Białystok: Wydawnictwo Prymat Mariusz Śliwkowski. 
Pobrane z czasopisma Studia Bia?orutenistyczne http://bialorutenistyka.umcs.pl Data: 26/04/2023 11:42:24

Polska i białoruska tożsamość Kościoła rzymskokatolickiego na Białorusi...

Tarasiuk, Dariusz. (2004). Kultura a świadomość narodowa Polaków na Białorusi na początku XX stulecia. W: Antoni Kruczyński, Małgorzata Michalska (red.). Kultura i świadomość etniczna Polaków na wschodzie. Tradycja i współczesność (s. 131-140). Wrocław: KEiAK UWr, OBW UWr.

Winnicki, Zdzisław, Julian. (2010). Tematy białorusko-polskie. Antologia. Wrocław: GS Media. Wierzbowska-Miazga, Agata (oprac.). (2001). Wybór dokumentów prawnych dotyczacych mniejszości narodowych. T. 2. Polacy na Białorusi. Warszawa: Stowarzyszenie „Wspólnota Polska".

Ziętek, Dorota. (2008). Tożsamość i religia. Ormianie w krakowskiej i lwowskiej diasporze. Kraków: Zakład Wydawniczy NOMOS.

Data nadesłania artykułu: 09.05.2018 